\title{
THE MODERATING INFLUENCE \\ OF CONSUMER DEMOGRAPHICS \\ ON THE RELATIONSHIP BETWEEN \\ PERCEIVED CSR AND BRAND LOYALTY \\ IN THE ROMANIAN RETAIL BANKING SECTOR
}

\author{
Ovidiu-loan Moisescu, Oana-Adriana Gică
}

\section{Introduction}

The relationship between brand loyalty and the extent to which companies are perceived by their customers as being socially responsible represents a relevant research topic, especially in the service industry, and particularly in the banking sector. Currently, even though the banking sector can be generally considered an oligopoly in most countries, competition among banks is intense, due to the decreasing level of their customers' inertia, as well as to the ease and velocity of switching banking services providers.

In this context, retaining customers and developing long-term customer relationships in the banking sector should take into consideration the link between corporate social responsibility (CSR) and brand loyalty, as well as specific demographic-based market segments, if demographic variables can be acknowledged as moderators of the relationship between CSR and brand loyalty. The relevance of this research topic is even more prominent due to the fact that, especially during the last decades, studies have linked both CSR and brand loyalty to several relevant business benefits.

Thus, by retaining existing customers strong competitive advantages can be gained (McMullan, 2005), brand loyalty being proved to be significantly and positively associated to business performance and long-term profitability (Salegna \& Goodwin, 2005).

Moreover, based on several scientific endeavors, researchers have suggested that if companies adopt, implement, and communicate CSR policies, and, consequently, are perceived as good corporate citizens, they can leverage or enhance employee attraction and retention (Kim \& Park, 2011), purchase decisions (Brown \& Dacin, 1997; Sen \& Bhattacharya, 2001; Becker-Olsen, Cudmore, \& Hill, 2006), and customer relationship (Sen \& Bhattacharya, 2001; Peloza \& Shang, 2011). Researchers have also argued that by being perceived as socially responsible, business organizations can turn customers into brand ambassadors and make them more resilient to negative brand news, while all these generate positive reactions from other stakeholders such as seeking employment with the company or invest in it (Du, Bhattacharya, \& Sen, 2010).

Given the above-outlined arguments and considering the level of competitiveness in the banking industry, it is extremely important that the relationship between brand loyalty and perceived CSR be deeply and thoroughly investigated in the specified context, as well as the influence of consumer demographics on the nature and extent of this relationship. Such a research endeavor can contribute to the literature on CSR and brand loyalty, and could also outline practical implications for efficient CSR implementation and communication in the banking industry, with direct and indirect effects on customer loyalty.

Moreover, considering the particular sociocultural and economic context of Central and Eastern European countries, very little is known about the relationship between perceived CSR and brand loyalty, both in general, and in the particular sector of banking services, and even less regarding the demographics-based dissimilarities of this relationship.

Under these considerations, the purpose of the current paper is to analyze the 
demographic discrepancies regarding the relationship between customers' perceptions of CSR and their loyalty towards retail banks within the particular context of Romania - one of the largest national markets of Central and Eastern Europe. Our investigation is based on data collected within a survey conducted among a large non-probabilistic sample of Romanian retail banking customers, taking into consideration several variables regarding the extent to which Romanians perceive their banking services providers as being socially responsible, and their loyalty towards these providers. Our results indicate several significant dissimilarities between gender, age, education, and residence type based consumer segments, concerning the impact of various CSR dimensions, as perceived by customers, on brand loyalty towards corporate brands in the Romanian retail banking sector.

The paper is further structured into four main sections. The first section includes a theoretical background and develops several research hypotheses, the second one describes the methodology of the research, the third one includes a detailed presentation of the results along with discussions, while the fourth and last section outlines the conclusions and implications of the research.

\section{Theoretical Background and Research Hypotheses}

In this section, after briefly describing the concepts on which the research is based (CSR and brand loyalty), we depict the theoretical background regarding the relationship between brand loyalty and perceived CSR in the banking sector, as well as concerning the correlations between consumers' demographics and their perceived relevance of CSR-related aspects, and, based on the depicted theoretical background, we develop several specific research hypotheses.

\subsection{The Concept of CSR}

CSR represents a complex, wide and, therefore, difficult to define concept. After analyzing no less than 37 definitions of CSR, Dahlsrud (2008) came to the conclusion that despite certain similarities among various definitions of CSR, a widely accepted definition in this case still remains an important issue in the literature.

From a general perspective, CSR can be regarded as a company's engagement in improving the social well-being through discretionary or philanthropic business practices and through contributing from its own resources (Kotler \& Lee, 2005). More specifically, CSR includes those voluntary activities that integrate economic, social and environmental concerns in business operations (Van Marrewijk, 2003).

Despite its complex nature, most of the approaches regarding CSR systematization and quantification can be reduced to three main categories: those based on stakeholders, those based on sustainability principles, and, respectively, those circumscribed to Carroll's (1979) view. From a stakeholder-based perspective (Freeman, Harrison, Wicks, Parmar, \& De Colle, 2010), CSR can be systematized into several dimensions, each being related to corporate responsibilities towards a certain stakeholder category: shareholders, customers, employees, the environment, the society etc. From a sustainability stand point (Kolk \& Van Tulder, 2010) CSR integrates economic, environmental and social responsibilities. Finally, Carroll's (1979) perspective on CSR regards it as a four-dimensional concept including economic, legal, ethical, and discretionary/philanthropic responsibilities of organizations.

\subsection{The Concept of Brand Loyalty}

Brand loyalty represents one of the most investigated concepts, especially in the marketing literature. However, during the last decades the concept has been subject to several divergent approaches, its definition and meaning being still a matter of debate in the literature, most of these issues originating from its dual nature: attitudinal and behavioral (Oliver, 1999).

Therefore, despite the apparent simplicity of some popular definitions such as the one provided by brand "guru" David A. Aaker (1991) who regards brand loyalty as a reflection of how likely a consumer is to switch to another brand, especially when that brand makes a change in marketing programs, we consider the original and classic definition of brand loyalty given by Jacoby and Chesnut (1978) as being more relevant and suited from a measurement perspective, the authors regarding it as a function of psychological processes consisting in the biased behavioral response expressed over time by consumers with respect to one or more alternative brands out of a set of brands. 
From this standpoint, many scholars have emphasized the fact that behavioral loyalty cannot distinguish between true loyalty and spurious loyalty (Dick \& Basu, 1994), psychological commitment and positive brand attitude being essential elements of the authenticity of brand loyalty.

\subsection{The Relationship between Brand Loyalty and Perceived CSR in the Banking Sector}

Investigating the relationship between brand loyalty and perceived CSR in the financial services industry represents a relevant and difficult research topic, brand loyalty in the service sector being more elusive and unpredictable as compared to other sectors (Vlachos \& Vrechopoulos, 2012).

After scrutinizing the main scientific literature sources one can be surprised by the fact that relevant research on this particular topic and, respectively, specific industry is rather scarce and mostly focused on Western and developed regions such as the USA (e.g. Walsh \& Beatty, 2007; Choi \& La, 2013), Spain (e.g. Marin, Ruiz, \& Rubio, 2009; Salmones, Pérez, \& Bosque, 2009; Matute-Vallejo, Bravo, \& Pina, 2011; Pérez, Salmones, \& Bosque, 2013), Australia (e.g. Chomvilailuk \& Butcher, 2014), or Austria (e.g. Öberseder, Schlegelmilch, Murphy, \& Gruber, 2014).

Thus, Walsh and Beatty (2007), after conducting a survey among American customers of banks, retailers and restaurants, concluded that perceptions regarding a company being customer orientated, a good employer, a reliable and financially strong company, or socially and environmentally responsible, all positively influence customer satisfaction, trust, and loyalty. American consumers were also investigated by Choi and La (2013) whose results suggest that perceived CSR has a significant impact on customer trust and loyalty in the context of service recovery (their sample including American students who had a recent service failure and recovery experience).

Spanish consumers have also been extensively investigated with regard to the impact of perceived CSR on brand loyalty in the financial services sector. Thus, Marin et al. (2009), after surveying customers of a regional bank from Spain, found that CSR has an indirect effect on brand loyalty, mediated by customer-company identification. Salmones et al. (2009) also conducted a survey among customers of financial services companies from Spain, their results showing that customer satisfaction, trust, and identification with the company are the main determinants of loyalty, ethical and social dimensions of CSR having an indirect effect, mediated by trust and customercompany identification. Matute-Vallejo et al. (2011) also surveyed customers of banks from Spain, showing that both CSR and price fairness indirectly contribute to achieving customer loyalty, with satisfaction and commitment as mediating variables. More recently, Pérez et al. (2013) investigated a sample of financial services companies' customers from Spain, suggesting that perceived CSR contributes to building consumer-company identification, which is positively correlated to satisfaction, while satisfaction along with consumercompany identification determine attitudinal customer loyalty.

Two other significant studies conducted on the topic regard the Austrian and the Australian markets. Öberseder et al. (2014), after conducting a survey among Austrian customers of a manufacturer, a FMCG company, and a bank, found a direct and positive relationship between customers' perceptions of CSR (towards customers, employees, the environment, community, society, shareholders, and suppliers) and their purchase intention, as well as an indirect one, mediated by customercompany identification. Similarly, Chomvilailuk and Butcher (2014), after surveying Australian bank customers, found that CSR perceptions have significant effects on purchase intentions and word of mouth.

Given the above-outlined theoretical background, and considering the purpose and context of the current research, the following research hypothesis was issued:

HO: There is a positive relationship between perceived CSR and brand loyalty in the retail banking sector.

\subsection{Consumers' Demographics and Perceived Relevance of CSR-Related Aspects}

As already stated, the literature is rather scarce with regard to research on the relationship between brand loyalty and perceived CSR in the financial services industry, being mostly focused on developed countries and regions. This scarcity is even more acute when it 
comes to considering demographic variables as potential moderators of the relationship between perceived CSR and brand loyalty. However, past research has tried to investigate the relationship between various demographic variables and consumers' knowledge, attitude and/or behavior related to socially responsible or sustainable products, demographics being widely used to profile the so-called 'green' consumers (Park, Choi, \& Kim, 2012).

Thus, Shrum, McCarty, and Lowrey (1995), after conducting a survey among U.S. citizens, noted significant gender based differences in consumers' interest in purchasing environmentally safe products.

Berger (1997), after analyzing data concerning Canadian households, came to the conclusion that education, income, size of residential area, and type of dwelling represent significant determinants of consumers' environmentally responsible behaviors.

Wiidegren (1998) investigated a nationwide sample of Swedish consumers and indicated that while education and income do not have any influence on pro-environmental behavior and willingness to pay higher prices for environmentally friendly products, gender and age could be considered important factors of these CSR related behaviors and attitudes. Partially similar results were obtained by Laroche, Bergeron, and Barbaro-Forleo (2001) who, after analyzing the profiles of Canadian consumers, concluded that gender and marital status significantly influence consumers' willingness to pay more for environmentally friendly products, while consumers' age, level of education, household income, as well as work status, do not play significant roles in developing such green attitudes.

Diamantopoulos, Schlegelmilch, Sinkovics, and Bohlen (2003) developed and tested, on a large nationwide sample of British citizens, several hypotheses concerning the relationship between consumers' environmental consciousness and their demographic characteristics. Their results showed that consumers' gender, age and educational level have a significant impact on their environmental knowledge, attitudes and behavior (including green purchasing behavior). These findings among UK consumers were partially confirmed by Smallbone (2005) who indicated that consumers' behavior and concern about sustainability issues correlate positively with their age and income.
However, after analyzing a sample of UK consumers, Gilg, Barr, and Ford (2005) came to the conclusion that even though age and income positively influence green consumption, gender does not have an influence in this direction.

More recently, Jansson, Marell, and Nordlund (2010) concluded, based on a survey conducted among consumers from Sweden, that age and education level have a significant negative influence on green curtailment behaviors, education and income have a significant positive influence on consumer adoption of innovations marketed as green, while there are no significant differences regarding the investigated issues between gender-based consumer categories.

Paço and Raposo (2010), after investigating a sample of Portuguese consumers, found that age, education, occupation and income (but not gender) are significant for differentiating between the 'greener' consumer group and the other segments. However, Abeliotis, Koniari, and Sardianou (2010), after examining the profile of the Greek green consumer, found age and income (but not gender and educational level) to be influential factors in determining engagement in reuse and recycle activities, while age, income and gender (but not educational level) were found to be significant in influencing sustainable consumption. Moreover, Pinto, Nique, Añaña, and Herter (2011), after conducting a survey among a sample of Brazilians, indicated that consumers' ecologically responsible consumption is positively influenced by age, negatively impacted by education, and not at all differentiated among gender based groups.

Park et al. (2012) also examined the influence of demographic variables on consumers' behavior and choices with regard to environmentally friendly products. Thus, after analyzing a sample of Canadian consumers, the authors concluded that females are more likely than males to be ecologically conscious, that the relative importance of products' green certification differs cross income levels, in a nonlinear way, while age and education are not significant in this direction. However, a different result was emphasized by Ansar (2013) who, after conducting a research among Pakistani residents, stated that no demographic variable (gender, age, income and education level being included in the analysis) is significantly related to consumers' green purchase intention. 
A more complex research approach was recently embraced by Kim, Lee, and Park (2010) who conducted a study among U.S. and Korean consumers in order to examine how much variance associated with brand loyalty was explained by fair trade product beliefs and corporate evaluation, including several demographic factors in their analysis as potential relationship moderators. Their results suggest that, at least in the case of American consumers, the relationship between brand loyalty and the variables related to fair trade, as part of corporate social responsibility, is significantly moderated by gender and age, and insignificantly determined by consumers' country of residence or occupation.

As it can be seen, past research regarding the correlations between consumers' demographics and their perceived relevance of CSR-related aspects has shown inconsistent findings. Nevertheless, the overall findings suggest that consumers' knowledge, attitudes and behavior with regard to socially responsible or sustainable products and companies can significantly differ among various demographicbased market segments. Therefore, given the above-outlined theoretical background, and taking into consideration the purpose and context of the current research, the following research hypotheses were issued:

H1: The relationship between perceived CSR and brand loyalty in the retail banking sector differs among gender-based market segments.

H2: The relationship between perceived CSR and brand loyalty in the retail banking sector differs among age-based market segments.

H3: The relationship between perceived CSR and brand loyalty in the retail banking sector differs among education-based market segments.

H4: The relationship between perceived CSR and brand loyalty in the retail banking sector differs among residence-based market segments.

\section{Methodology}

In this section, we describe the research objectives, the research design, and the primary data collection method, providing details regarding the variables used in order to measure perceived CSR and brand loyalty, as well as relevant information concerning the investigated sample. This section also includes a preliminary analysis of the data, based on an exploratory factor analysis, as well the proposed multiple linear regression model, in which demographic variables such as gender, age, education and residence type were included as potential moderators.

\subsection{Research Objectives, Research Design, and Primary Data Collection Method}

Given the business benefits of CSR and brand loyalty, and considering the level of competitiveness in the banking sector, it is important to examine the relationship between brand loyalty and perceived CSR in this industry, as well as the influence of consumer demographics on the nature and extent of this relationship. Such a research endeavor can contribute to the literature on CSR and brand loyalty, and could also outline practical implications for efficient CSR implementation and communication in the banking industry, with direct and indirect effects on customer loyalty.

The current research investigates the moderating influence of consumer demographics on the relationship between customers' perceptions of CSR and their corporate brand loyalty towards retail banks in Romania, one of the largest countries of Central and Eastern Europe.

The primary data were collected using a selfadministered paper and pencil questionnaire which included 34 items (Tab. 1) for measuring CSR perceptions (28 items) and brand loyalty (6 items). All items were measured using Likert scales ranging from $1=$ "strongly disagree" to $7=$ "strongly agree", with a middle/neutral point.

The initial list of items was drawn up from relevant literature sources concerning the assessment of brand loyalty (Zeithaml, Berry, \& Parasuraman, 1996; Cronin, Brady, \& Hult, 2000; Sloot, Verhoef, \& Franses, 2005; Rosenbaum, 2006; Martínez \& Bosque, 2013), and the quantification of consumers' perception of CSR (Maignan, 2001; Salmones, Crespo, \& Bosque, 2005; Wagner, Bicen, \& Hall, 2008; Turker, 2009; Öberseder et al., 2014; Pérez \& Bosque, 2013). The initial list was afterwards purified by identifying and removing those items which were considered ambiguous, redundant or imperceptible to potential respondents.

The CSR measurement item-pool was set so as to reflect all dimensions of the concept, 
both from sustainable development perspective (comprising items regarding economic, environmental, and social responsibilities), and a stakeholder-based standpoint (including items to reflect responsibilities towards shareholders, customers, employees, society, public authorities).

The questionnaires were distributed, thoroughly explained, self-administrated, recovered and systematized between January and March 2015. The sampling technique was non-probabilistic, based on potential respondents' willingness to participate in the study, and consisted of quota sampling by gender and age, the final sample comprising 1,449 retail banking customers, most of them $(85.5 \%)$ being users of the financial services provided by the four main banks activating in Romania: 554 customers (38.23\%) of Banca Transilvania (owned by the BT Financial Group from Romania), 295 customers (20.36\%) of BCR (owned by the Erste Group from Austria), 245 customers $(16.91 \%$ ) of BRD (owned by the Société Générale Group from France), and 145 customers (10\%) of Raiffeisen Bank (owned by Raiffeisen Banking Group from Austria).

Respondents' gender and education level were measured as nominal data: "male" or "female" in the case of gender, and, respectively, "primary school, middle school or high-school", "BA university degree", "MA university degree" or "PhD degree or higher" in the case of education level. However, for the purpose of this research and considering the sample's educational level distribution, the variable referring to respondents' education was recoded in order to generate two comparable similar-sized groups ("no university degree" or "university degree - BA, MA, or higher"). Age was measured as ordinal data (respondents stating their actual age, in years) and further on recoded so that it would also generate two comparable similar-sized groups ("up to 35 years" or "more than 35 years"). Finally, in what concerns the size of each respondent's city of residence, this variable was initially measured as nominal data (respondents stating their current city of residence); afterwards it was recoded so that the sample be divided into two comparable similar-sized groups, considering the current size of each specified city ("cities with up to 100,000 inhabitants" and "cities with more than 100,000 inhabitants").

Considering its demographic structure, the sample comprised $712(49.14 \%)$ men and 737 (50.86\%) women, 756 (52.17\%) respondents aged up to 35 years and 693 (47.83\%) older, 717 (49.48\%) subjects with a university degree (BA, MA, or higher) and $732(50.52 \%)$ without higher education, and, respectively, 759 (52.38\%) respondents from cities with up to 100,000 inhabitants and $690(47.62 \%)$ from larger cities.

\subsection{Preliminary Analysis and Proposed Model}

In order to operationalize the research, the large number of observed variables (34 items) was firstly reduced to a limited number of reflective latent variables after an exploratory

\section{Tab. 1: Observable and latent variables - Part 1}

\begin{tabular}{l|l|c|c} 
Latent variables & \multicolumn{1}{|c|}{ Observable variables (items) } & Based on* & Load $^{* *}$ \\
\hline $\begin{array}{l}\text { Responsibility } \\
\text { towards } \\
\text { shareholders }\end{array}$ & $\begin{array}{l}\text { Strives to maximize profits and improve economic } \\
\text { performance }\end{array}$ & {$[1,2,3,4]$} & .861 \\
\cline { 2 - 4 } & $\begin{array}{l}\text { Pursues its success in the long term, not only in the short } \\
\text { term }\end{array}$ & {$[1,2,3,4]$} & .810 \\
\hline $\begin{array}{l}\text { Responsibility } \\
\text { towards } \\
\text { customers }\end{array}$ & Strives to offer its customers services of reasonable quality & {$[2]$} & .697 \\
\cline { 2 - 4 } & Is concerned with its customers' satisfaction & {$[3,5]$} & .727 \\
\cline { 2 - 4 } & Provides honest \& complete information about its services & {$[2,3,5,6]$} & .762 \\
\cline { 2 - 4 } & Charges fair and reasonable prices for its services & {$[2,6]$} & .742 \\
\cline { 2 - 4 } & $\begin{array}{l}\text { Provides safe services, not-threatening to physical/mental } \\
\text { health }\end{array}$ & {$[2,6]$} & .671 \\
\cline { 2 - 4 } & Works diligently to handle and solve its customers' complaints & {$[2,3]$} & .686 \\
\hline
\end{tabular}




\section{Tab. 1: Observable and latent variables - Part 2}

\begin{tabular}{|c|c|c|c|}
\hline Latent variables & Observable variables (items) & Based on* & Load** $^{* *}$ \\
\hline \multirow{6}{*}{$\begin{array}{l}\text { Responsibility } \\
\text { towards } \\
\text { employees }\end{array}$} & Pays its employees fairly and in a reasonable manner & {$[2,3,6]$} & .702 \\
\hline & Offers its employees decent working conditions & {$[2,3,6]$} & .749 \\
\hline & Does everything possible to prevent employees discrimination & {$[2,3,6]$} & .778 \\
\hline & Respects the rights of its employees & {$[1,2,5]$} & .839 \\
\hline & Treats its employees with respect & [6] & .822 \\
\hline & $\begin{array}{l}\text { Provides development \& promotion opportunities } \\
\text { to employees }\end{array}$ & {$[2,3,5]$} & .700 \\
\hline \multirow{4}{*}{$\begin{array}{l}\text { Responsibility } \\
\text { towards the } \\
\text { environment }\end{array}$} & $\begin{array}{l}\text { Does everything possible to reduce effects on the } \\
\text { environment }\end{array}$ & {$[2,3,5,6]$} & .702 \\
\hline & $\begin{array}{l}\text { Minimizes resources consumption that affect the } \\
\text { environment }\end{array}$ & [2] & .821 \\
\hline & Works diligently to use environmentally friendly materials & {$[2,3,5,6]$} & .839 \\
\hline & $\begin{array}{l}\text { Is concerned with waste management and recycling } \\
\text { activities }\end{array}$ & {$[2,6]$} & .754 \\
\hline \multirow{7}{*}{$\begin{array}{l}\text { Responsibility } \\
\text { towards } \\
\text { community } \\
\text { development }\end{array}$} & Contributes to the regional economic growth \& development & [2] & .694 \\
\hline & Contributes to the welfare and life quality in the region & {$[1,3,4,5]$} & .687 \\
\hline & Creates and sustains jobs in the region & [2] & .771 \\
\hline & $\begin{array}{l}\text { Contributes to the development of other companies in the } \\
\text { region }\end{array}$ & [2] & .724 \\
\hline & Respects the values, customs and culture of the region & [2] & .595 \\
\hline & $\begin{array}{l}\text { Supports charitable/social projects aimed at the } \\
\text { disadvantaged }\end{array}$ & {$[1,2,3,4,5]$} & .648 \\
\hline & Supports cultural and social events (music, sports, etc.) & {$[3,4]$} & .640 \\
\hline \multirow{3}{*}{$\begin{array}{l}\text { Responsibility } \\
\text { towards public } \\
\text { authorities }\end{array}$} & $\begin{array}{l}\text { Fully complies with the legislation in conducting its } \\
\text { activities }\end{array}$ & {$[1,4,5,6]$} & .730 \\
\hline & Always pays state taxes in a fairly and honestly manner & {$[5,6]$} & .805 \\
\hline & $\begin{array}{l}\text { Tries to prevent \& avoid corruption in its relation with the } \\
\text { state }\end{array}$ & [6] & .758 \\
\hline \multirow[t]{6}{*}{ Brand loyalty } & I consider myself a loyal customer of this bank & {$[9,10]$} & .695 \\
\hline & This bank is my first choice, compared to others in the sector & {$[8,11]$} & .775 \\
\hline & I will continue to be a customer of this bank & {$[7,8]$} & .745 \\
\hline & In the future I plan to purchase more services from this bank & [11] & .724 \\
\hline & I would recommend this bank to my friends \& acquaintances & {$[7,8,11]$} & .738 \\
\hline & $\begin{array}{l}\text { I wouldn't give up being a customer even if a competitor } \\
\text { came up with a better offer }\end{array}$ & [11] & .598 \\
\hline
\end{tabular}

Note: * [1] Maignan, 2001; [2] Öberseder et al., 2014; [3] Pérez \& Bosque, 2013; [4] Salmones et al., 2005; [5] Turker, 2009; [6] Wagner et al., 2008; [7] Cronin et al., 2000; [8] Martínez \& Bosque, 2013; [9] Rosenbaum, 2006; [10] Sloot et al., 2005; [11] Zeithaml et al., 1996.

${ }^{* *}$ Component loadings according to exploratory factor analysis using Varimax rotation (IBM SPSS Statistics 20). 


\section{Fig. 1: Proposed multiple regression model}



Source: own

factor analysis with Varimax rotation. As it can be seen in Tab. 1, the six loyalty indicators were adequately grouped into a single latent variable, while the 28 perceived CSR items were clustered into six components: responsibilities towards shareholders, customers, employees, the environment, community development, and, respectively, public authorities.

From a statistical standpoint, the conducted factor analysis' reliability is appropriate: the Kaiser-Meyer-Olkin value $\mathrm{KMO}=.937$ indicates excellent sampling adequacy, the Bartlett's test of sphericity (chi-square $=31,609.326$; $\mathrm{df}=561$; $p<.001$ ) suggests appropriate correlations in the data set, and the resulted latent variables explain a total of almost $70 \%(68.565 \%)$ of their common variance.

After assigning each latent variable a score equal to the mean value of its reflecting items, a multiple regression model was proposed (Fig. 1) in which the latent variables regarding CSR perceptions were considered predictors, while the latent variable corresponding to brand loyalty was treated as dependent variable.

Furthermore, the proposed model was successively tested using multiple linear regression analyses within various demographics-based consumer segments, in order to test the issued hypotheses.

\section{Results and Discussion}

Results in Tab. 2 convey the general conclusion that customers' loyalty towards their banks is positively and significantly impacted by how they perceive their financial services providers' overall CSR, confirming hypothesis HO. More specifically, in both gender categories, the variance in brand loyalty accounted for by customers' perceptions of CSR is very close to $50 \%: 47.7 \%$ in the case of men, and, respectively, $49.2 \%$ in the case of women. As it can be seen, in both cases the most influential dimension of perceived CSR consists of banks' responsibility towards customers $($ Beta $=.546 / .593 ; p<.001)$, while customers' perceptions regarding their banks' responsibilities towards shareholders or employees do not significantly impact brand loyalty.

However, even though both men and women are loyalty-sensitive with regard to how they perceive their banks' responsibilities towards community development, brand loyalty among male customers is slightly more influenced by this CSR perception as compared 
to female customers (Beta $=.114$ and $p=.003$ versus Beta $=.076$ and $p=.022$ ). Two other important gender-based dissimilarities in the relationship between perceived CSR and brand loyalty can also be outlined: on one hand, brand loyalty is influenced by perceived responsibility towards the environment only in the case of female customers (Beta $=.079$; $p=.017$ ), while, on the other hand, perceived responsibility towards public authorities is only relevant for brand loyalty in the case of male customers (Beta $=.080 ; p=.021)$. Considering the above described findings, hypothesis $\mathrm{H} 1$ is accepted.

The similar overall impact of perceived CSR on brand loyalty in both cases (men and women) is consistent with the findings of Gilg et al. (2005), Jansson et al. (2010), Pinto et al. (2011), Paço and Raposo (2010), and Ansar (2013), none of these researchers finding any significant influence of gender on consumers' attitudes towards sustainable products.

The fact that brand loyalty is influenced by perceived responsibility towards the environment only in the case of female customers is in accordance with the findings of Diamantopoulos et al. (2003) who showed that gender has a significant impact on environmental knowledge, attitudes and behavior, as well as with the results obtained by Park et al. (2012) who emphasize that women are more likely than men to be ecologically conscious. Similar findings were actually outlined by Shrum et al. (1995), Wiidegren (1998), Laroche et al. (2001), and Abeliotis et al. (2010), all these researchers stating that gender plays a significant role in consumers' green consumption and willingness to pay more for environmentally friendly products.

Moreover, the dissimilarities between men and women in what concerns the impact of perceived responsibilities towards community development and public authorities on brand loyalty are consistent with the findings of Kim et al. (2010) who indicated that the relationship between brand loyalty and the variables related to fair trade is significantly moderated by gender.

Results in Tab. 3 are partially consistent with those previously outlined in Tab. 2 . Thus, it can be restated that in all analyzed segments customers' loyalty towards their banks is positively and significantly impacted by how they perceive their banks' overall CSR (hypothesis $\mathrm{HO}$ being thus confirmed), the most influential dimension of perceived CSR consisting of banks' responsibility towards customers $($ Beta $=.537 / .608 ; p<.001)$. The impact of perceived responsibility towards community development is also significant (Beta $=.078$ and $p=.021$; Beta $=.108$ and $p=.003$ ), while customers' perceptions regarding their banks' responsibility towards employees do not significantly impact brand loyalty.

Nevertheless, the variance in brand loyalty accounted for by customers' perceptions of CSR is slightly different among the two age categories: $46 \%$ in the case of those aged up to 35 years, and, respectively, $51.5 \%$ in the case of older customers.

However, only younger bank customers are loyalty-sensitive with regard to their

Tab. 2: Multiple regression standardized coefficients: men versus women

\begin{tabular}{|c|c|c|c|c|c|c|}
\hline & \multicolumn{3}{|c|}{ Men } & \multicolumn{3}{|c|}{ Women } \\
\hline & Beta & $\mathbf{t}$ & $\mathrm{p}$ & Beta & $\mathbf{t}$ & $p$ \\
\hline Shareholders & -.058 & -1.901 & .058 & -.047 & -1.616 & .106 \\
\hline Customers & .546 & 15.030 & .000 & .593 & 18.352 & .000 \\
\hline Employees & .070 & 1.955 & .051 & .053 & 1.572 & .116 \\
\hline Environment & .028 & .817 & .414 & .079 & 2.393 & .017 \\
\hline Community development & .114 & 3.023 & .003 & .076 & 2.299 & .022 \\
\hline \multirow[t]{2}{*}{ Public authorities } & .080 & 2.312 & .021 & .044 & 1.306 & .192 \\
\hline & \multicolumn{3}{|c|}{$\mathrm{R}^{2}=.477 ; \mathrm{F}(6,705)=107.33 ; p<.001$} & \multicolumn{3}{|c|}{$R^{2}=.492 ; F(6,730)=117.99 ; p<.001$} \\
\hline
\end{tabular}


Tab. 3: Multiple regression standardized coefficients: younger versus older

\begin{tabular}{l|c|c|c|c|c|c} 
& \multicolumn{3}{|c|}{$<=35$ years } & \multicolumn{3}{c}{$>35$ years } \\
\cline { 2 - 8 } & Beta & $\mathbf{t}$ & $\mathbf{p}$ & Beta & $\mathbf{t}$ & $\mathbf{p}$ \\
\hline Shareholders & -.026 & -.854 & .393 & -.079 & -2.706 & .007 \\
\hline Customers & .537 & 15.652 & .000 & .608 & 17.850 & .000 \\
\hline Employees & .066 & 1.936 & .053 & .063 & 1.795 & .073 \\
\hline Environment & .087 & $\mathbf{2 . 6 6 5}$ & .008 & -.001 & -.019 & .985 \\
\hline Community development & .078 & $\mathbf{2 . 3 0 6}$ & .021 & .108 & $\mathbf{2 . 9 8 0}$ & .003 \\
\hline Public authorities & .057 & 1.700 & .090 & .076 & $\mathbf{2 . 1 7 6}$ & .030 \\
\hline & \multicolumn{2}{|c|}{$\mathrm{R}^{2}=.460 ; \mathrm{F}(6,749)=106.17 ; \mathrm{p}<.001$} & $\mathrm{R}^{2}=.515 ; \mathrm{F}(6,686)=121.63 ; \mathrm{p}<.001$ \\
\hline
\end{tabular}

Source: own data processing (IBM SPSS Statistics 20)

banks' responsibility towards the environment (Beta $=.087 ; p=.008)$, while brand loyalty is impacted by perceived CSR towards public authorities $($ Beta $=.076 ; p=.030)$ and shareholders (Beta $=-.079 ; p=.007$ ) only in the case of older customers. It is also important to emphasize the fact that in this latter case the impact on brand loyalty is negative, older bank customers being less loyal to their banks if they perceive them as being too focused on profitability and business performance. Considering these findings, hypothesis $\mathrm{H} 2$ is accepted.

The finding that the overall impact of perceived CSR on brand loyalty is larger in the case of older customers is consistent with the results of Smallbone (2005) who state that consumers' behavior and concern about sustainability issues correlates positively with their age, and with those of Kim et al. (2010), who indicate that the relationship between brand loyalty and the variables related to fair trade (as a component of corporate social responsibility) is significantly moderated by age.

The fact that only younger bank customers could be emphasized as loyalty-sensitive with regard to their banks' responsibility towards the environment is both consistent and inconsistent with past research. Thus, the findings of Gilg et al. (2005), who state that age positively influence green consumption, and those of Pinto et al. (2011), who indicate that consumers' ecologically responsible consumption is positively influenced by age, strongly contradict this paper's results. Our results are also inconsistent with other previous findings such as those of Laroche et al. (2001), Park et al. (2012) and Ansar (2013) who could not identify any significant influence of age on consumers' behavior and choices with regard to environmentally friendly products. However, our

\section{Tab. 4: Multiple regression standardized coefficients: lower versus higher educated}

\begin{tabular}{l|c|c|c|c|c|c}
\multirow{2}{*}{} & \multicolumn{3}{|c|}{ No university degree } & \multicolumn{3}{c}{ University degree } \\
\cline { 2 - 7 } & Beta & $\mathbf{t}$ & $\mathbf{p}$ & Beta & $\mathbf{t}$ & $\mathbf{p}$ \\
\hline Shareholders & -.030 & -.988 & .323 & -.076 & $\mathbf{- 2 . 6 1 9}$ & .009 \\
\hline Customers & .563 & $\mathbf{1 6 . 6 0 6}$ & .000 & .583 & $\mathbf{1 6 . 7 4 8}$ & .000 \\
\hline Employees & .071 & $\mathbf{2 . 0 5 4}$ & .040 & .045 & 1.268 & .205 \\
\hline Environment & .018 & .549 & .583 & .083 & $\mathbf{2 . 4 7 3}$ & .014 \\
\hline Community development & .103 & $\mathbf{2 . 9 5 2}$ & .003 & .080 & $\mathbf{2 . 2 5 0}$ & .025 \\
\hline Public authorities & .077 & 2.299 & .022 & .056 & 1.603 & .109 \\
\hline & \multicolumn{3}{l}{$\mathrm{R}^{2}=.474 ; \mathrm{F}(6,725)=108.97 ; \mathrm{p}<.001$} & \multicolumn{2}{l}{$\mathrm{R}^{2}=.495 ; \mathrm{F}(6,710)=115.98 ; \mathrm{p}<.001$} \\
\hline
\end{tabular}


results are in accordance with Diamantopoulos et al. (2003) who identify several past studies which emphasize that younger members of the population exhibit higher levels of environmental consciousness.

Results in Tab. 4 are less consistent with those previously outlined in Tab. 2 and Tab. 3 . Consistencies refer to the fact that hypothesis $\mathrm{HO}$ is confirmed in all analyzed segments, customers' loyalty towards their banks being positively and significantly impacted by how they perceive their banks' overall CSR (the variance in brand loyalty accounted for by customers' perceptions of CSR being relatively similar for the two education-based consumer segments: $47.4 \%$ and $49.5 \%$ ). Moreover, in both education categories banks' responsibility towards customers is the most influential dimension of perceived CSR $($ Beta $=.563 / .583$; $\mathrm{p}<.001)$.

However, only less educated bank customers' loyalty is significantly impacted by how they perceive their banks' responsibilities towards employees (Beta $=.071 ; p=.040)$ and public authorities (Beta $=.077 ; p=.022$ ), while only higher educated customers are loyalty-sensitive with regard to their banks' responsibilities towards the environment (Beta $=.083 ; p=.014)$ and shareholders (Beta $=-.076 ; p=.009)$. It is again important to emphasize the fact that in this latter case the impact on brand loyalty is negative, higher educated bank customers being less loyal to their banks if they perceive them as being too focused on profitability and business performance. Considering the above described dissimilarities, hypothesis $\mathrm{H} 3$ is accepted.

Our findings indicating that the variance in brand loyalty accounted for by customers' overall perceptions of CSR is relatively similar for the two education-based consumer segments is consistent with previous studies' results such as those of Wiidegren (1998), Laroche et al. (2001), Abeliotis et al. (2010), Park et al. (2012), and Ansar (2013), none of these researchers identifying any significant influence of consumers' education on their attitudes towards sustainable products.

If the particular responsibility towards the environment is taken into consideration, our findings are in accordance with previous research conducted by Berger (1997), Diamantopoulos et al. (2003), Jansson et al. (2010), and, respectively, Paço and Raposo
(2010), all of these authors emphasizing that there is a significant positive influence of consumers' educational level on their attitude and behavior towards environmentally friendly products/companies. However, our results do not support the findings of Pinto et al. (2011) who outlined that consumers' ecologically responsible consumption is negatively impacted by education.

Results in Tab. 5 present several common findings as compared to those previously emphasized. Thus, no matter the size of the city consumers reside in, their corporate brand loyalty is positively and significantly influenced by how they perceive their banks' overall CSR, hypothesis HO being confirmed (customers' perceptions of CSR accounting for almost $50 \%$ of the variance in brand loyalty in both segments). Moreover, perceptions regarding companies' responsibilities towards customers $($ Beta $=.575 / .567 ; p<.001)$ and community development $($ Beta $=.084$ with $p=.020$, and Beta $=.122$ with $p=.001$ ) are significant predictors of brand loyalty in both cases.

Nevertheless, brand loyalty is significantly impacted by how customers perceive their banks' responsibility towards employees only in the case of bank customers residing in smaller cities (Beta $=.073 ; p=.036)$, while only those residing in larger cities are loyalty-sensitive with regard to how they perceive their banks' responsibilities towards public authorities (Beta $=.089 ; p=.009$ ) and shareholders (Beta $=-.063 ; p=.041$ ). As within previous results, in this latter case the impact on brand loyalty is negative, bank customers from larger cities being less loyal to their banks if they perceive them as being too focused on profitability and business performance. Finally, considering the findings above, hypothesis $\mathrm{H} 4$ is accepted.

Even though past research has tried to investigate the relationship between demographic variables and consumers' attitudes towards sustainable products, variables related to the size of consumers' residential areas have generally been ignored. One of the very few studies which take this demographic variable into consideration is that of Berger (1997) who concludes that the size of consumers' residential area represents a significant determinant of their environmentally responsible behavior. Berger's (1997) results do not contradict our findings which emphasize the fact that banks' perceived responsibility 
Tab. 5: Multiple regression standardized coefficients: smaller versus larger cities

\begin{tabular}{|c|c|c|c|c|c|c|}
\hline & \multicolumn{3}{|c|}{ Cities with $<=100,000$ inhabitants } & \multicolumn{3}{|c|}{ Cities with $>100,000$ inhabitants } \\
\hline & Beta & $t$ & $p$ & Beta & $t$ & p \\
\hline Shareholders & -.047 & -1.648 & .100 & -.063 & -2.043 & .041 \\
\hline Customers & .575 & 16.588 & .000 & .567 & 16.816 & .000 \\
\hline Employees & .073 & 2.099 & .036 & .041 & 1.166 & .244 \\
\hline Environment & .065 & 1.901 & .058 & .032 & .977 & .329 \\
\hline Community development & .084 & 2.338 & .020 & .122 & 3.455 & .001 \\
\hline \multirow[t]{2}{*}{ Public authorities } & .037 & 1.068 & .286 & .089 & 2.608 & .009 \\
\hline & \multicolumn{3}{|c|}{$R^{2}=.499 ; F(6,752)=124.69 ; p<.001$} & \multicolumn{3}{|c|}{$R^{2}=.468 ; F(6,683)=100.05 ; p<.001$} \\
\hline
\end{tabular}

Source: own data processing (IBM SPSS Statistics 20)

towards the environment doesn't significantly impact their customers' loyalty neither in the case of those residing in smaller cities, nor in the case of those living in larger ones.

\section{Conclusions and Implications}

This paper manages to fill a regional knowledge gap regarding the moderating influence of consumer demographics on the relationship between perceived CSR and brand loyalty in the retail banking sector of Romania, one of the largest Central-Eastern European countries.

The results indicate that, regardless of consumer demographics, brand loyalty is positively and significantly influenced by how customers' perceive their banks' overall CSR, perceptions regarding companies' responsibilities towards customers and community development being significant predictors of brand loyalty in all demographicsbased categories.

However, there are certain demographicsbased dissimilarities in what concerns the relationship between perceived CSR and brand loyalty in the Romanian retail banking sector. Thus, brand loyalty is influenced by perceived responsibility towards the environment only in the case of female customers, while, on the other hand, perceived responsibility towards public authorities is only relevant for brand loyalty in the case of male customers. Moreover, only younger bank customers are loyalty-sensitive with regard to their banks' responsibility towards the environment, while brand loyalty is impacted by perceived CSR towards public authorities and shareholders only in the case of older customers. Also, only less educated bank customers' loyalty is significantly impacted by how they perceive their banks' responsibilities towards employees and public authorities, while only higher educated customers are loyalty-sensitive with regard to their banks' responsibilities towards the environment and shareholders. Last but not least, brand loyalty is significantly impacted by how customers perceive their banks' responsibility towards employees only in the case of bank customers residing in smaller cities, while only those residing in larger cities are loyalty-sensitive with regard to how they perceive their banks' responsibilities towards public authorities and shareholders.

It is also important to emphasize that, even though for most of the analyzed CSR dimensions customers' perceptions are positively associated with brand loyalty, in the case of banks' responsibilities towards shareholders the impact on brand loyalty is negative. Thus, bank customers who are older, higher educated or residing in larger cities are less loyal to their banks if they perceive them as being too focused on profitability and business performance.

The findings have practical implications related to the adequate CSR implementation and communication in the Central-Eastern European retail banking industry. Starting from the premises that banks regard the enforcement of their customers' loyalty as a strategic direction, and that the benefits and business returns of CSR are contingent on stakeholders' (in this case customers) awareness of CSR activities (Du et al., 2010), the paper conveys the idea that those banks which activate in 
in the specific context of Central-Eastern European countries should be focused on communicating their responsibility towards customers in all demographics-based market segments, and, depending on the market segment they are targeting, should selectively convey their responsibility towards employees, the environment, community development and/or public authorities. Moreover, in certain demographics-based market segments, banks' focus on business performance, profitability and shareholders' satisfaction should be carefully conveyed within the public, as this could negatively impact their customers' loyalty.

The main limitations of our current paper consist of the fact that potential mediating factors of the relationship between customers' perceptions of CSR and brand loyalty were not included in our model. However, this represents a future research opportunity, our analysis being extendable by taking into consideration several mediating variables such as customer satisfaction, customer trust, companyconsumer identification etc. and integrating them into a structural equation model along with perceptions of CSR as exogenous variables and brand loyalty as endogenous.

\section{References}

Aaker, D. A. (1991). Managing Brand Equity: Capitalizing on the Value of a Brand Name. New York: The Free Press.

Abeliotis, K., Koniari, C., \& Sardianou, E. (2010). The profile of the green consumer in Greece. International Journal of Consumer Studies, 34(2), 153-160. doi:10.1111/j.14706431.2009.00833.x.

Ansar, N. (2013). Impact of green marketing on consumer purchase intention. Mediterranean Journal of Social Sciences, 4(11), 650-655. doi:10.5901/mjss.2013.v4n11p650.

Becker-Olsen, K. L., Cudmore, B. A., \& Hill, R. P. (2006). The impact of perceived corporate social responsibility on consumer behavior. Journal of Business Research, 59(1), 46-53. doi:10.1016/j.jbusres.2005.01.001.

Berger, I. E. (1997). The demographics of recycling and the structure of environmental behavior. Environment and Behavior, 29(4), 515-531. doi:10.1177/001391659702900404.

Brown, T. J., \& Dacin, P. A. (1997). The company and the product: corporate associations and consumer product responses.
The Journal of Marketing, 61(1), 68-84. doi:10.2307/1252190.

Carroll, A. B. (1979). A Three-Dimensional Conceptual Model of Corporate Performance. Academy of Management Review, 4(4), 497-505. doi:10.2307/257850.

Choi, B., \& La, S. (2013). The impact of corporate social responsibility (CSR) and customer trust on the restoration of loyalty after service failure and recovery. Journal of Services Marketing, 27(3), 223-233. doi:10.1108/08876041311330717.

Chomvilailuk, R., \& Butcher, K. (2014). Effects of quality and corporate social responsibility on loyalty. The Service Industries Journal, 34(11), 938-954. doi:10.1080/0264206 9.2014.915952.

Cronin Jr, J. J., Brady, M. K., \& Hult, G. T. M. (2000). Assessing the effects of quality, value, and customer satisfaction on consumer behavioral intentions in service environments. Journal of Retailing, 76(2), 193-218. doi:10.1016/s0022-4359(00)00028-2.

Dahlsrud, A. (2008). How corporate social responsibility is defined: an analysis of 37 definitions. Corporate Social Responsibility and Environmental Management, 15(1), 1-13. doi:10.1002/csr.132.

Diamantopoulos, A., Schlegelmilch, B. B., Sinkovics, R. R., \& Bohlen, G. M. (2003). Can socio-demographics still play a role in profiling green consumers? A review of the evidence and an empirical investigation. Journal of Business Research, 56(6), 465-480. doi:10.1016/S01482963(01)00241-7.

Dick, A., \& Basu, K. (1994). Customer Loyalty: Toward an Integrated Conceptual Framework. Journal of the Academy of Marketing Science, 22(2), 99-113. doi:10.1177/0092070394222001.

Du, S., Bhattacharya, C. B., \& Sen, S. (2010). Maximizing business returns to corporate social responsibility (CSR): The role of CSR communication. International Journal of Management Reviews, 12(1), 8-19. doi:10.1111/j.1468-2370.2009.00276.x.

Freeman, R. E., Harrison, J. S., Wicks, A. C., Parmar, B. L., \& De Colle, S. (2010). Stakeholder theory: the state of the art. Cambridge: Cambridge University Press.

Gilg, A., Barr, S., \& Ford, N. (2005). Green consumption or sustainable lifestyles? Identifying the sustainable consumer. Futures, 37(6), 481-504. doi:10.1016/j.futures.2004.10.016. 
Jacoby, J., \& Chesnut, R. W. (1978). Brand Loyalty: Measurement and Management. New York: John Wiley \& Sons.

Jansson, J., Marell, A., \& Nordlund, A. (2010). Green consumer behavior: determinants of curtailment and eco-innovation adoption. Journal of Consumer Marketing, 27(4), 358370. doi:10.1108/07363761011052396.

Kim, S. Y., \& Park, H. (2011). Corporate social responsibility as an organizational attractiveness for prospective public relations practitioners. Journal of Business Ethics, 103(4), 639-653. doi:10.1007/s10551-011-0886-x.

Kim, G. S., Lee, G. Y., \& Park, K. (2010). A cross-national investigation on how ethical consumers build loyalty toward fair trade brands. Journal of Business Ethics, 96(4), 589611. doi:10.1007/s10551-010-0486-1.

Kolk, A., \& Van Tulder, R. (2010). International business, corporate social responsibility and sustainable development. International Business Review, 19(2), 119-125. doi:10.1016/j.ibusrev.2009.12.003.

Kotler, P., \& Lee, N. (2005). Corporate Social Responsibility: Doing the Most Good for Your Company and Your Cause. Hoboken, NJ: John Wiley.

Laroche, M., Bergeron, J., \& BarbaroForleo, G. (2001). Targeting consumers who are willing to pay more for environmentally friendly products. Journal of Consumer Marketing, 18(6), 503-520. doi:10.1108/EUM0000000006155.

Maignan, I. (2001). Consumers' perceptions of corporate social responsibilities: a crosscultural comparison. Journal of Business Ethics, 30(1), 57-72. doi:10.1023/A:1006433928640.

Marin, L., Ruiz, S., \& Rubio, A. (2009). The role of identity salience in the effects of corporate social responsibility on consumer behavior. Journal of Business Ethics, 84(1), 65-78. doi:10.1007/s10551-008-9673-8.

Martínez, P., \& del Bosque, R. I. (2013). CSR and customer loyalty: The roles of trust, customer identification with the company and satisfaction. International Journal of Hospitality Management, 35, 89-99. doi:10.1016/j. ijhm.2013.05.009.

Matute-Vallejo, J., Bravo, R., \& Pina, J. M. (2011). The influence of corporate social responsibility and price fairness on customer behaviour: evidence from the financial sector. Corporate Social Responsibility and Environmental Management, 18(6), 317-331. doi:10.1002/csr.247.
McMullan, R. (2005). A multiple-item scale for measuring customer loyalty development. Journal of Services Marketing, 19(7), 470-481. doi:10.1108/08876040510625972.

Öberseder, M., Schlegelmilch, B. B., Murphy, P. E., \& Gruber, V. (2014). Consumers' Perceptions of Corporate Social Responsibility: Scale Development and Validation. Journal of Business Ethics, 124(1), 101-115. doi:10.1007/ s10551-013-1787-y.

Oliver, R. L. (1999). Whence consumer loyalty? The Journal of Marketing, 63(1), 33-44. doi:10.2307/1252099.

Paço, A. M. F., \& Raposo, M. L. B. (2010). Green consumer market segmentation: empirical findings from Portugal. International Journal of Consumer Studies, 34(4), 429-436. doi:10.1111/j.1470-6431.2010.00869.x.

Park, S. J., Choi, S., \& Kim, E. J. (2012). The Relationships between Socio-demographic Variables and Concerns about Environmental Sustainability. Corporate Social Responsibility and Environmental Management, 19(6), 343-354. doi:10.1002/csr.284.

Peloza, J., \& Shang, J. (2011). How can corporate social responsibility activities create value for stakeholders? A systematic review. Journal of the Academy of Marketing Science, 39(1), 117-135. doi:10.1007/s11747-010-0213-6.

Pérez, A., \& del Bosque, I. R. (2013). Measuring CSR image: three studies to develop and to validate a reliable measurement tool. Journal of Business Ethics, 118(2), 265-286. doi:10.1007/s10551-012-1588-8.

Pérez, A., de los Salmones, M. G., \& del Bosque, I. R. (2013). The effect of corporate associations on consumer behaviour. European Journal of Marketing, 47(1/2), 218-238. doi:10.1108/03090561311285529.

Pinto, D. C., Nique, W. M., Añaña, E. D. S., \& Herter, M. M. (2011). Green consumer values: how do personal values influence environmentally responsible water consumption? International Journal of Consumer Studies, 35(2), 122-131. doi:10.1111/j.1470-6431.2010.00962.x.

Rosenbaum, M. S. (2006). Exploring the social supportive role of third places in consumers' lives. Journal of Service Research, 9(1), 59-72. doi:10.1177/1094670506289530.

Salegna, G. J., \& Goodwin, S. A. (2005). Consumer loyalty to service providers. An integrated conceptual model. Journal of Consumer Satisfaction, Dissatisfaction and Complaining Behavior, 18(1), 51-67. 
Salmones de los, M. G., Crespo, A. H., \& del Bosque, I. R. (2005). Influence of corporate social responsibility on loyalty and valuation of services. Journal of Business Ethics, 61(4), 369-385. doi:10.1007/s10551-005-5841-2.

Salmonesdelos, M. G.,Pérez,A., \&delBosque, I. R. (2009). The social role of financial companies as a determinant of consumer behaviour. International Journal of Bank Marketing, 27(6), 467-485. doi:10.1108/02652320910988339.

Sen, S., \& Bhattacharya, C. B. (2001). Does doing good always lead to doing better? Consumer reactions to corporate social responsibility. Journal of Marketing Research, 38(2), 225-243. doi:10.1509/ jmkr.38.2.225.18838.

Shrum, L. J., McCarty, J. A., \& Lowrey, T. M. (1995). Buyer characteristics of the green consumer and their implications for advertising strategy. Journal of Advertising, 24(2), 71-82. doi:10.1080/00913367.1995.10673477.

Sloot, L. M., Verhoef, P. C., \& Franses, P. H. (2005). The impact of brand equity and the hedonic level of products on consumer stockout reactions. Journal of Retailing, 81(1), 15-34. doi:10.1016/j.jretai.2005.01.001.

Smallbone, T. (2005). How can domestic households become part of the solution to England's recycling problems? Business Strategy and the Environment, 14(2), 110-122. doi:10.1002/bse.442.

Turker, D. (2009). Measuring corporate social responsibility: A scale development study. Journal of Business Ethics, 85(4), 411-427. doi:10.1007/s10551-008-9780-6.

Van Marrewijk, M. (2003). Concepts and definitions of CSR and corporate sustainability: between agency and communion. Journal of Business Ethics, 44(2-3), 95-105. doi:10.1007/978-94-007-4126-3_32.
Vlachos, P. A., \& Vrechopoulos, A. P. (2012). Consumer-retailer love and attachment: Antecedents and personality moderators. Journal of Retailing and Consumer Services, 19(2), 218-228. doi:10.1016/j. jretconser.2012.01.003.

Wagner, T., Bicen, P., \& Hall, Z. R. (2008). The dark side of retailing: towards a scale of corporate social irresponsibility. International Journal of Retail \& Distribution Management, 36(2), 124-142. doi:10.1108/09590550810853075.

Walsh, G., \& Beatty, S. E. (2007). Customerbased corporate reputation of a service firm: scale development and validation. Journal of the Academy of Marketing Science, 35(1), 127143. doi:10.1007/s11747-007-0015-7.

Wiidegren, Ö. (1998). The new environmental paradigm and personal norms. Environment and Behavior, 30(1), 75-100. doi:10.1177/0013916598301004.

Zeithaml, V. A., Berry, L. L., \& Parasuraman, A. (1996). The behavioral consequences of service quality. The Journal of Marketing, 60(1), 31-46. doi:10.2307/1251929.

\section{Assoc. Prof. Ovidiu-loan Moisescu, Ph.D.} Babeș-Bolyai University Faculty of Economics and Business Administration Department of Marketing ovidiu.moisescu@econ.ubbcluj.ro

Lect. Oana-Adriana Gică, Ph.D. Babes-Bolyai University Faculty of Business Department of Hospitality Services oana.gica@tbs.ubbcluj.ro 


\section{Abstract}

\section{THE MODERATING INFLUENCE OF CONSUMER DEMOGRAPHICS ONTHE RELATIONSHIP BETWEEN PERCEIVED CSR AND BRAND LOYALTY INTHE ROMANIAN RETAIL BANKING SECTOR}

\section{Ovidiu-Ioan Moisescu, Oana-Adriana Gică}

The current research investigates the moderating influence of consumer demographics on the relationship between customers' perceptions of corporate social responsibility (CSR) and their corporate brand loyalty towards retail banks in Romania, a typical developing country and one of the largest countries of Central and Eastern Europe. The investigation is based on data collected within a survey conducted among a sample of 1,449 Romanian retail banking customers, based on a questionnaire including a specific set of items drawn up from the literature, intended to reflect corporate brand loyalty, as well as perceptual CSR dimensions, from a sustainable development and stakeholder-based perspective. After an exploratory factor analysis, the observed variables were grouped into several latent variables regarding perceived CSR and brand loyalty and, further on, these were included into a multiple regression model which was tested comparatively within various sample groups generated based on consumer demographics variables. The results emphasize several significant dissimilarities between gender, age, education and residence type based consumer segments in what concerns the impact of various CSR dimensions, as perceived by customers, on brand loyalty towards corporate brands in the banking sector. Thus, brand loyalty is significantly influenced by: perceived responsibility towards the environment - only in the case of female, younger and/or higher educated customers; perceived responsibility towards public authorities - only in the case of customers who are male, older, less educated and/or residing in larger cities; by perceived responsibility towards shareholders - only when for customers who are older, higher educated and/or residing in larger cities. The findings have practical implications for enhancing corporate brand loyalty in the regional retail banking sector market by outlining those CSR policies, actions and attitudes which should have priority within local banks' marketing communications.

Key Words: CSR, brand loyalty, consumer demographics, retail banking.

JEL Classification: M31.

DOI: 10.15240/tul/001/2017-4-013 